\title{
韓国のプレジャーボート政策発展のための研究 一日本と英国との安全政策比較を中心に一
}

\author{
金 連珍 ${ }^{1}$ 藤本 昌志 $^{2} \cdot$ 藤原 紗衣子 $^{2} \cdot$ 㴊 $^{\text {真輝 }}{ }^{2}$ \\ The development of the Pleasure Boat Policy in Korea \\ - The comparison to safety policies between Korea, \\ Japan and UK -
}

\author{
Yeonjin KIM, Shoji FUJIMOTO, Saeko FUJIWARA and Masaki FUCHI
}

\begin{abstract}
In past years, rare marine leisure activities were conducted within Korean water. Korean government currently focus on promoting the pleasure boat activities with the purpose of developing it as the new tourism industry. However, with the increasing of pleasure boat activities within Korean water, more and more marine accidents or collisions between pleasure boats appear gradually. It also brings Korean government the new issue to manage marine activities such as pleasure boats in safe. Actually, it seems insufficient to achieve the captioned purpose only by setting the relevant laws and regulations for leisure boats. Further measures to improve the safety of marine pleasure boat activities should be considered additionally.

Therefore, this paper will discuss (1) The current situation of pleasure boats in Korea, (2) The comparison to safety policies between Korea, Japan and UK (3) The suggestion to develop Korean marine leisure culture. This paper will also propose the direction to improve safe activities from personal, organizational and governmental aspects respectively.
\end{abstract}

Keywords : legal policy, Korea, pleasure boat, marine leisure, safety policy キーワード: 立法政策、韓国、プレジャーボート、海洋レジャー、安全政策

\section{1. はじめに}

\section{1 研究の背景}

韓国は歴史的に農業を中心とした文化が発達し ており、海を忌避する土俗信仰の影響もあって、海 を中心とする文化は発展してこなかった。観光やレ ジャー施設に対する関心も内陸優先で、海洋レジャ 一活動への関心は高まっていなかった ${ }^{(1)}$ 。

しかし 韓国政府は国の新しい成長戦略として海 洋に注目し、2000 年に国家レベルの海洋水産発展総

\footnotetext{
学生会員 神戸大学大学院海事科学研究科（† 658-0022

2 正会員神戸大学大学院海事科学研究科（广658-0022
}

合計画である第一次海洋水産発展基本計画を樹立し、 海洋の体系的管理に取り組み始めた。その後 2003 年には海洋観光振興基本計画を樹立し、海洋観光の 一つの軸として海洋レジャー活動の活性化を推進し ている(2)

国家レベルではマリーナ施設の拡充とマリーナ の新設、マリーナサービス産業の活性化対策、海洋 レジャー装備開発の支援、海洋レジャ一体験教室の 支援、海洋スポーツ大会や海洋レジャー博覧会の開

神戸市東灘区深江南町 5-1-1)

神戸市東灘区深江南町 5-1-1) 


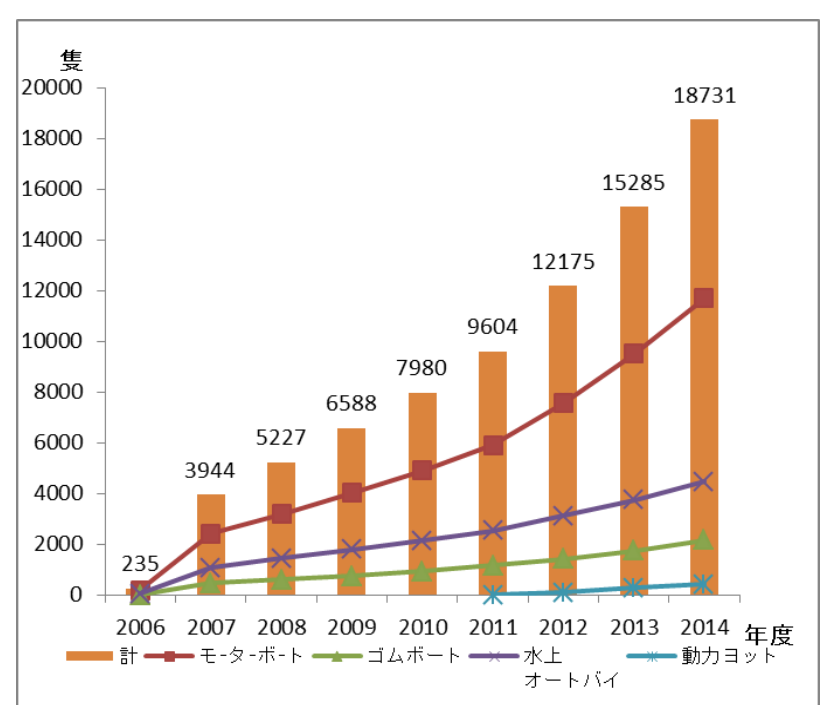

図 1 韓国のプレジャーボート登録隻数

（2012 年度までのデータは「2013 海洋警察白書 ${ }^{(3)} 」$ から、2014 年度までのデータは「2015 国民安全処 統計年報 ${ }^{(4)} 」$ から著者らが作成)

催を支援する等、海洋レジャーの基盤の構築に取り 組んでいる。自治体でも地域経済の発展を図る各種 海洋レジャーイベントを開催するなど、海洋レジャ 一を体験する機会を増やしている。

政府、自治体の努力及び個人の余暇時間の増加、 生活の質を重視するウェルビーイング (Wel1 Being) 文化の普及、アウトドア活動の人気などが影響し、 海洋レジャ一活動の需要は増加傾向にある。韓国の 海洋レジャー文化は導入段階であるため、プレジャ 一ボートの活動に関する公式的統計はとられていな いが、登録される船舶数の増加推移から利用者の増 加を推察することが可能である。

韓国でプレジャーボートの登録制が始まった 2006 年にはその対象隻数が 235 隻に過ぎなかったが、 毎年持続的に増加し 2014 年には約 80 倍の 18,731 隻に至っている。さらに 2011 年以降は機関付きヨッ 卜の登録隻数が増えると共に、全体の増加が加速す る傾向も見せている(図 1 参照)。

韓国で海洋レジャー活動が確認されている海域 は 533 ヶ所あり、その内の 392 ケ所 $(73.5 \%)$ が事業 場のある海域である。事業場とは、水上レジャー安 全法による許可を得て有料で海洋レジャー装備のレ ンタルやプレジャーボートの搭乗体験が出来る所で ある。海洋レジャー活動者を対象にした 2011 年の海 洋水産部の調査によると、調査対象の $91 \%$ が個人レ ベルの趣味活動であり同好会等の団体活動は少ない。 個人装備を保有している活動者は $28 \%$ で、72\%の活動

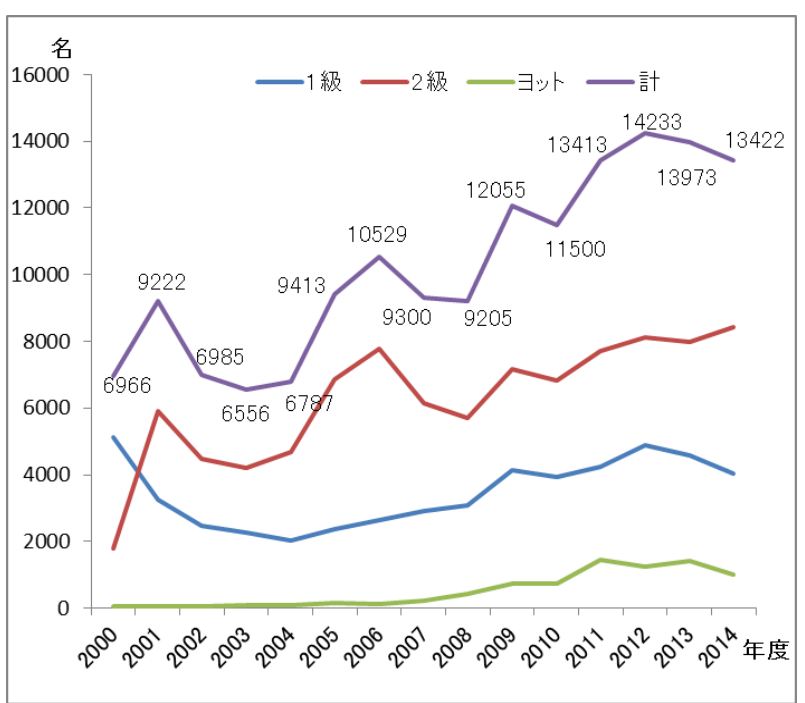

図 2 韓国の操縦免許取得者数

(図 1 と同じ出典で著者らが作成)

者は事業場などでのレンタル装備を利用している ${ }^{(5)}$ 。 この調査から韓国の海洋レジャー活動は個人単位で、 事業場でのレンタル装備を利用した活動を中心に利 用者が増加してきたことが分かる。

一方で、図 1 の登録隻数の増加から個人のボート 所有が増え、その活動も増えることも予測できる。 潜在的活動者である操縦免許取得者の数も年平均 1 万人以上増え続けている (図 2 参照)。また、プレジ ヤーボート活動の増加により、プレジャーボート海 難も増加している。韓国で 2005 年から 2015 年まで 発生しているプレジャーボート海難は 2,917 件で、 その中、比較的軽微な事故である単純漂流が 835 件 と機関故障が 1, 210 件で、全体の約 $70 \%$ を占めてい る (表 1 参照)。しかし、衝突や座礁、沈没などの人

表 1 プレジャーボート海難発生の推移

\begin{tabular}{|c|c|c|c|c|c|c|c|c|c|c|}
\hline 年度 & 計 & 浸水 & 火災 & 転覆 & 座礁 & 衝突 & 沈没 & $\begin{array}{c}\text { 機闢 } \\
\text { 㳊 }\end{array}$ & 漂流 & $\begin{array}{c}\text { その } \\
\text { 他 }\end{array}$ \\
\hline 2005 & 9 & 0 & 0 & 4 & 1 & 2 & 0 & 0 & 0 & 2 \\
\hline 2006 & 45 & 2 & 2 & 4 & 0 & 1 & 0 & 12 & 0 & 24 \\
\hline 2007 & 158 & 1 & 0 & 10 & 3 & 3 & 0 & 75 & 1 & 65 \\
\hline 2008 & 162 & 6 & 0 & 8 & 2 & 1 & 0 & 76 & 27 & 42 \\
\hline 2009 & 324 & 12 & 2 & 9 & 4 & 5 & 7 & 87 & 148 & 50 \\
\hline 2010 & 298 & 9 & 0 & 12 & 8 & 5 & 2 & 70 & 134 & 58 \\
\hline 2011 & 352 & 15 & 1 & 13 & 11 & 12 & 3 & 113 & 117 & 67 \\
\hline 2012 & 348 & 16 & 2 & 16 & 8 & 6 & 4 & 91 & 141 & 64 \\
\hline 2013 & 365 & 7 & 2 & 12 & 6 & 18 & 3 & 43 & 236 & 38 \\
\hline 2014 & 323 & 13 & 3 & 25 & 10 & 14 & 4 & 61 & 175 & 18 \\
\hline 2015 & 533 & 22 & 2 & 25 & 19 & 8 & 5 & 207 & 231 & 14 \\
\hline $\begin{array}{c}\text { 計 } \\
(\%)\end{array}$ & $\begin{array}{c}2917 \\
(100)\end{array}$ & $\begin{array}{c}103 \\
(3.5)\end{array}$ & $\begin{array}{c}14 \\
(0.5)\end{array}$ & $\begin{array}{c}138 \\
(4.7)\end{array}$ & $\begin{array}{c}72 \\
(2.5)\end{array}$ & $\begin{array}{c}75 \\
(2.6)\end{array}$ & $\begin{array}{c}28 \\
(1.0)\end{array}$ & $\begin{array}{c}835 \\
(28.6)\end{array}$ & $\begin{array}{c}1210 \\
(41.5)\end{array}$ & $\begin{array}{c}442 \\
(15.2)\end{array}$ \\
\hline
\end{tabular}

(韓国国民安全処水上レジャ一総合情報システム) 
命や財産被害の大きい事故も徐々に増えている(図 3 参照)。

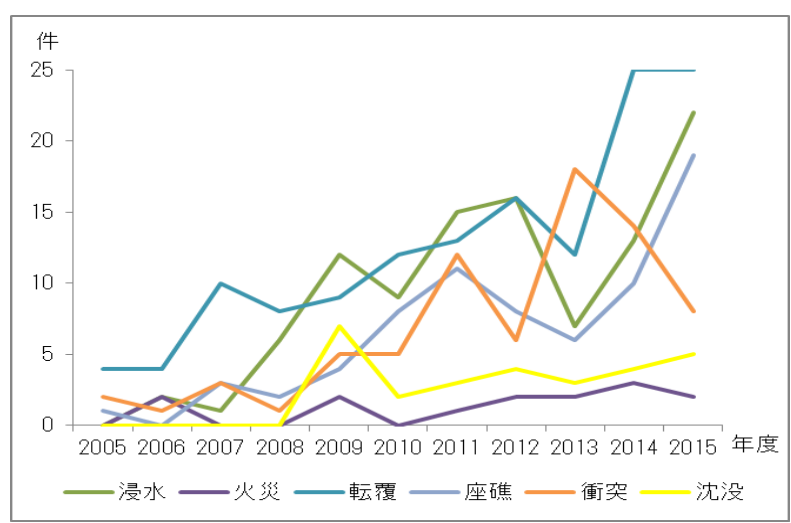

困 3 人命や財産被害の大きいプレジャーボート 海難の推移(表 1 から著者らが作成)

\section{2 研究の目的}

海洋レジャーに対する政策的努力と個人的関心 の高揚は、利用者の数と登録隻数の増加に繋がって いる。一定の海面を利用する船舶の増加は、衝突な どの海難発生の蓋然性を高めるものである。

このような現状において、プレジャーボート活動 の安全を確保するために韓国では規制中心の様々な 政策を推進しているが、増加する海洋レジャ一需要 への対応として十分であるとは言えない。

日本は 1970 年代以降、国民生活水準の向上や余 暇時間の拡大に伴いプレジャーボートの活動が急増 してきたが(6)、その様相は、韓国の現状と類似した ところが多い。一方、英国は昔からヨット等のボー 卜活動が生活に溶け込んでいる国である(7)。日本に おけるプレジャーボート活動者の急増に対态してき た安全対策を研究することと、英国における自主的 安全活動を研究することは、これからの韓国の海洋 レジャー安全政策の立案に貢献できると考える。

\section{2. 韓国のプレジャーボート安全政策}

韓国におけるプレジャーボートの安全管理は、大 部分が「水上レジャ一安全法 ${ }^{(8)} 」 に$ 基づいて行われ ている。2000年に制定されたこの法律は水上レジャ 一活動の安全及び秩序を確保し、水上レジャー事業 の健全な発展を図ることを目的とし、水上レジャー 機具の登録と検査、操縦免許、安全遵守義務、水上 レジャー事業者の資格と義務を主要内容にしている。 この法律の適用対象である「水上レジャ一機具」と は、水上で趣味・娛楽・体育・教育の目的で利用される
20 トン未満の船舶及び機具をいう。その中で推進機 関を有するモーターボート、機関付きヨット、ゴム ボート (機関出力 30 馬力以上で折り畳めない形態の もの)、水上オートバイ等を「動力水上レジャー機具」 と分類し、船舶の登録や検査、操縦免許取得等の義 務の対象としている。海難審判の船種の分類からプ レジャーボートとは、モーターボート、水上オート バイ、ヨット等水上レジャーに供される船舶として いるので、本論ではその対象と活動の内容が同様で あることから「動力水上レジャー機具」をプレジャ 一ボートと示す。

\section{1 船舶の登録と検査}

韓国のプレジャーボートの登録制度は、個人所有 のプレジャーボートの増加による財産権の保護、盗 難防止及び安全管理の必要性により 2006 年 4 月から 導入された。

登録の対象は推進機関を有する水上オートバイ、 総トン数 20 トン未満のヨットとモーターボート、折 りたたんで運搬できないゴムボートであり、日本の ミニボートの登録免除のような船体の大きさと機関 馬力による例外はない。

登録の手続きは政府指定機関の安全検査受検後、 責任保険に加入し、管轄自治体に登録すると登録番 号を交付される。

ボートの登録には検査証書が必要であるため、登 録対象になるプレジャーボートは例外なく安全検査 が必要である。安全検査の代行機関は船舶安全技術 公団と韓国水上レジャー安全連合会で、検査は新規 登録時の新規検査、船舶の構造と装置を変更した際 の臨時検査、登録後 5 年毎に定期的に受検する定期 検査がある。特に、レジャ一事業に用いられる船舶 は毎年定期検査を受けなければならない。

表 2 プレジャーボート登録と検査制度の比較

\begin{tabular}{|c|c|c|c|}
\hline & 韓国 & 日本 & 英国 \\
\hline 担当 & \begin{tabular}{|l} 
管轄自治体 (登録) \\
船舶安全技術公団、 \\
韓国水上レジャー安 \\
全連合会(検査)
\end{tabular} & 日本小型船舶検査機構 & 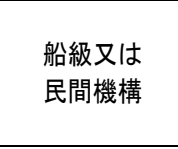 \\
\hline 法的 & $\begin{array}{c}\bigcirc \\
\text { 水上レジャ一安全法 }\end{array}$ & \begin{tabular}{|l}
$\mathrm{O}$ \\
小型船舶の登録等に関 \\
する法律 (登録) \\
船舶安全法(検査) \\
\end{tabular} & $\begin{array}{c}X \\
\text { 所有者の希望時 } \\
\text { 可能(商船法) }\end{array}$ \\
\hline 対象 & \begin{tabular}{|l|}
-20トン未満の機関 \\
付きヨット、モータ \\
一ボート \\
$\cdot$ 水上オートバイ \\
·折畳めない $30 \mathrm{hp} \mathrm{以}$ \\
上のゴムボート
\end{tabular} & $\begin{array}{l}\text { ·総トン数 } 20 \text { トン } \\
\text { 未満の船舶 } \\
\text { ·船体の大きさ、機関 } \\
\text { 馬カによる例外対象 } \\
\text { 在り }\end{array}$ & - \\
\hline
\end{tabular}




\section{2 操縦免許}

韓国でプレジャーボートを操縦するためには国 民安全処の長官が発給する「動力水上レジャー機具 操縦免許」と称する操縦免許が必要である。操縦免 許は一般操縦免許とヨット操緹免許に区分される。 一般操縦免許の取得で操縦可能な船舶は、ヨットを 除く全ての最大出力 5 馬力以上のプレジャーボート である。一般操縦免許は 1 級と 2 級に区分されるが、 一般操縦者は 2 級の取得で全てのプレジャーボート の操縦が可能となる。1 級は、レジャー事業者や操 縦免許試験の監督官、安全教育の講師に必要な資格 で、ボートの運航可能区域や操縦能力による区別で はない。ヨット操縦免許は動力ヨットを操縦するた めに必要な免許で、帆走には一般ボートと異なる知 識と技術が必要であるため別途に区分している。免 許取得の可能年齢は 14 歳以上で、筆記試験と実技試 験の合格と安全講習の履修が必要である。免許の有 効期限は 7 年で、更新には安全講習の履修が必要で ある。

表 3 プレジャーボート操縦免許制度の比較

\begin{tabular}{|c|c|c|c|}
\hline & 韓国 & 日本 & 英国 \\
\hline $\begin{array}{l}\text { 法的 } \\
\text { 義務 }\end{array}$ & $\begin{array}{l}\bigcirc \\
\text { 水上レジャ一安全法 }\end{array}$ & $\begin{array}{c}\bigcirc \\
\text { 船舶職員及び小型船舶 } \\
\text { 操縦者法 }\end{array}$ & $X$ \\
\hline 名称 & $\begin{array}{c}\text { 動力水上レジャー } \\
\text { 操縦免許 }\end{array}$ & 小型船舶操縱免許 & \multirow{4}{*}{$\begin{array}{c}\text { 操縦能力 } \\
\text { 認定のため } \\
\text { RYA が } \\
14 \text { 種類の } \\
\text { 資格証発給 }\end{array}$} \\
\hline 機関 & 国民安全処 & $\begin{array}{c}\text { 日本海洋レジャー安全·振 } \\
\text { 興協会 }\end{array}$ & \\
\hline 区分 & $\begin{array}{l}\cdot \text { 一般操縱免許 } 1 \text { 級 } \\
\text {-レジャー事業用 } \\
\text { 一般操縱免許 } 2 \text { 級 } \\
\text {-全ての最大 } 5 \text { hp 以上 } \\
\text { 動カ水上レジャ一機 } \\
\text { 具(ヨット除外) } \\
\text {-運航区域、操縦能力 } \\
\text { 区別なし } \\
\text {-ヨット操縦免許 } \\
\text {-機関付きヨット }\end{array}$ & $\begin{array}{l}\text { 一級小型船舶操縦士 } \\
\text {-全ての水域で小型船 } \\
\text { 舶航海可能 } \\
\cdot \text { 二級小型船舶操縦士 } \\
- \text {-海岸 5 海里航海可能 } \\
\cdot \text { 二級(湖川小出力限定) } \\
-5 \text { トン及び機関出カ } \\
15 \mathrm{~kW} \text { 未満 } \\
\text {-湖川及び-部海域限定 } \\
\cdot \text { 特殊小型船舶操縦士 } \\
\text {-水上オートバイ } \\
\text { ※特殊小型船舶は保有 } \\
\text { 免許のレベルを問わず } \\
\text { 運航区域制限あり }\end{array}$ & \\
\hline 更新 & $\begin{array}{c}7 \text { 年 } \\
\text { 更新講習必要 }\end{array}$ & $\begin{array}{c}5 \text { 年 } \\
\text { 身体検査と更新講習必要 }\end{array}$ & \\
\hline $\begin{array}{l}\text { 事業 } \\
\text { 免許 }\end{array}$ & 一般操縦免許 1 級 & $\begin{array}{l}\text { 特定操縦免許 } \\
\text {-操縱免許取得＋小型 } \\
\text { 旅客安全講習受講 }\end{array}$ & $\begin{array}{c}\text { AALA の } \\
\text { 資格証必要 }\end{array}$ \\
\hline
\end{tabular}

\section{3 活動に関する規制}

\subsection{1 安全遵守義務}

韓国はプレジャーボート活動者の安全を守るた め様々な規制を設定し、活動を制限してきた。プレ ジャーボート運航時の操縦者の安全遵守義務を主に
定めている法律は、水上レジャー安全法とその下位 法令である水上レジャ一安全法施行令と水上レジャ 一安全法施行規則である。

水上レジャー安全法で定めている安全遵守義務 は救命胴衣などの安全装備着用、運航規則遵守、出 発港から 10 海里以上運航時に必要な遠距離活動申 告の義務、無免許操縦の禁止、夜間活動の禁止(夜間 運航装備保有船舶は除く)、飲酒操縦の禁止等である。

水上レジャー安全法施行令により詳細な運航規 則が規定されているが、その内容は運航時の見張り、 船舶間の衝突を予防するための航法及び飛び込夕台、 係留場、橋梁から $20 \mathrm{~m}$ 以内等の危険海域での低速 $(10$ ノット以下) 運航、注意報以上の気象警報の発令時運 航の禁止、0.5km 以内の視程不良時運航禁止 (レーダ 一及びVHF 設置船舶を除く)などを含めている。

\section{3.2 活動海域の制限}

韓国に登録される船舶は、船舶安全法に基づきそ の大きさと航海装備の能力別に航行区域が指定され る。航行区域は平水、沿海、近海、遠洋の区域に区 分されるが、長さ $12 \mathrm{~m}$ 未満の船舶は最も狭い範囲で、 湖、河川、港湾の水域を含める平水区域に指定され る。大半のプレジャーボートがこの区域に該当され る。

韓国ではプレジャーボートに対しては航行区域の 指定に加え、活動範囲を制限する規制として水上レ ジャー禁止区域と海洋レジャー許可区域を設定して いる。

水上レジャ一禁止区域とは、水上レジャ一活動の 安全確保のため水上レジャー安全法に基いて、年中 或いは一定の期間中の全てのレジャー活動を禁止す る区域である。海洋警備安全署長又は自治体の長が 指定する区域で、2015 年末で全国の海水浴場の周辺 等(164 ヶ所)を中心に 182 ヶ所が指定されている ${ }^{(9)}$ 。 海洋レジャ一許可区域とは、レジャー活動者の安 全よりも海上交通秩序の確保のため、海事安全法に よりレジャー活動が制限される区域である。海事 安全法の第 34 条は港湾と漁港水域の中で、海洋警 備安全署長が指定する一定海域での海上交通障害行 為を禁じているが、この海上交通障害行為は海事安 全法施行令で「水上レジャー機具を利用した活動」 と明確に規定している。

海洋レジャー許可区域でのレジャー活動を希望す る場合は、事前に管轄海洋警備安全署長の許可が必 要である。活動希望者が許可申請書を提出し、その 
活動が海上交通安全に障害をもたらさないと認めら れると活動許可書が発給されるが、この処理に最大 5 日かかる。

各活動区域制限の違反時には過料が科されるが、 水上レジャ一禁止区域は 100 万ウォン以下、海洋レ ジャー許可区域は 300 万ウォン以下である。

表 4 プレジャーボート活動規制の比較

\begin{tabular}{|c|c|c|c|}
\hline & 韓国 & 日本 & 英国 \\
\hline $\begin{array}{l}\text { 法的 } \\
\text { 規制 }\end{array}$ & $\begin{array}{c}\bigcirc \\
\text { 水上レジャ一安全法 } \\
\text { 海事安全法 } \\
\end{array}$ & $\begin{array}{c}\bigcirc \\
\text { 船舶職員及び小型船 } \\
\text { 舶操縦者法 }\end{array}$ & $X$ \\
\hline 内容 & $\begin{array}{l}\text { ·遵守事項 } \\
\text {-危険操縦の禁止 } \\
\text { 安全装備の着用、 } \\
\text { 無免許、飲酒操縱禁止、 } \\
\text { 遠距離活動の申告 } \\
\text { (10 海里以上航海時) } \\
\text { 夜間活動の禁止 } \\
\text { (夜間航海装備 } \\
\text { 用意時可能) } \\
\text { ·水上レジャ一禁止 } \\
\text { 区域、許可区域指定 }\end{array}$ & $\begin{array}{l}\text { 最低限の遵守事項 } \\
\text {-飲酒操縱等の禁止 } \\
\text { 免許者の自己操縦 } \\
\text { 救命胴衣の着用 } \\
\text { 見張りの実施等 }\end{array}$ & 法的規制なし \\
\hline
\end{tabular}

\section{4 海難の防止と対応}

韓国におけるプレジャーボートの安全管理は国民 安全処の海洋警備安全本部が担当している(以前の 海洋警察庁から 2014 年のセウォル号転覆事故後の 措置として組織改編)。プレジャーボートの安全管理 は予防対策よりも、事故発生後の対応を中心に行わ れて来た。

個人のボートより事業場でのレンタルボートを 利用する活動の割合が大きいので、海洋警備安全本 部のプレジャーボート海難防止活動も事業場の施設 点検と従事者対象の安全教育等の指導活動を中心に 行われていた。

個人単位のプレジャーボート活動者を対象にする 活動としては、遠距離活動申告船舶に対する出港前

表 5 プレジャーボート海難対応活動の比較

\begin{tabular}{|c|c|c|c|}
\hline & 韓国 & 日本 & 英国 \\
\hline $\begin{array}{l}\text { 政府 } \\
\text { 活動 }\end{array}$ & $\begin{array}{l}\text { ·国民安全処 } \\
\text { - 事業場の安全指導 } \\
\text { - 救助活動 } \\
\text { (応急措置 曳航) }\end{array}$ & $\begin{array}{l}\text { 海上保安庁 } \\
\text { - 海難防止及び敖助活動 } \\
\text { - 沿岸域情報提供 }\end{array}$ & $\begin{array}{l}\cdot \text {-MCA } \\
\text { - 民間活動 } \\
\text { 支援 }\end{array}$ \\
\hline 皆間 & -自律的安全活動不足 & $\begin{array}{l}\cdot \text { 小型船安全協会 } \\
\text { - 海上安全指導員 } \\
\text { 日本水難救済会 } \\
\text { - 水難救助活動 } \\
\cdot \text { 日本海洋レジャー安全·振 } \\
\text { 興協会 } \\
\text { - BAN(会員制救助システム) }\end{array}$ & $\begin{array}{l}\cdot \text { RNLI } \\
\text {-海洋救助 } \\
\text { 活動主導 }\end{array}$ \\
\hline
\end{tabular}

安全点検と 2015 年から施行したプレジャーボート 所有者への携帯電話メッセージ発送程度で、一般海 域での活動者を対象にする海難防止活動はまだ十分 とは言えない。

現状では海上でプレジャーボートの海難が発生 した場合、現場の確認、人命救助や応急措置の初期 対応から最寄りの港への曳航まで全てを海洋警備安 全本部が担当している。

\section{3. 外国のプレジャーボート関連政策 \\ 3.1 日本の政策}

日本のプレジャーボート保有隻数は日本小型船 舶検查機構の 2015 年末における在籍船統計データ 一で、特殊小型船舶が 62, 109 隻、プレジャーモータ ーボートが 172, 663 隻、プレジャーヨットが 10, 243 隻の計 245,015 隻で表 1 の韓国の登録隻数の 13 倍で ある(10)。

日本には韓国のようなプレジャーボートのみを 対象にする法令はなく、小型船舶の一種として管理 しているが、船舶の登録は小型船舶の登録等に関す る法律、検査は船舶安全法、免許制度は船舶職員及 び小型船舶操縦者法に規定されている。

小型船舶の登録と検査は日本小型船舶検査機構 の主管で、総トン数 20 トン未満の船舶の中で、登録 の対象類型を船体の大きさ、機関出力等により分離 適用している。

検査は受検時期と内容で定期検査、中間検查、臨 時検查、臨時航行検查に分けられ、船舶の種類によ ってその内容と期間が異なる。

小型船舶操縦免許は、 1 級· 2 級小型船舶操縦士と 水上オートバイ用の特殊小型船舶操緹士免許に区分 されており、操縦可能な船舶の種類と海域範囲の差 でレベルが分けられている。事業者の場合、小型船 舶で人を運送する旅客船、遊漁船の操縦には小型船 舶操縦士試験の合格に加えて、小型旅客安全講習を 受講し特定操縦免許を取得する必要がある。

免許の取得年齢は 18 歳以上であるが、2 級小型船 舶操縦免許と特殊小型船舶操縦免許は 16 歳以上で 取得可能である。

免許の取得には、直接、身体検査、筆記試験、実 技試験の小型船舶操縦士国家試験を受験する受験コ 一スと、登録小型船舶教習所において一定期間講習 を受講した後、国家試験と同等の内容の学科及び実 技修了試験を受験し、合格すれば国家試験の学科と 実技が免除される教習コースの二つの方法がある。 
免許の有効期限は 5 年で、更新には身体検査と更 新講習の受講が必要である ${ }^{(11)}$ 。

日本においてプレジャーボートの活動を特別に制 限する法律はないが、安全を担保するための最低限 のマナーとして、船舶職員及び小型船舶操縦者法に 飲酒操縦等の禁止、免許者の自己操縌、救命胴衣の 着用、見張りの実施等の遵守事項を規定している。

また、活動地域によっては地方条例等の規則や自 治体・関係団体等で自主ルールが運用されていると ころがある。

プレジャーボートの安全管理に関わる政府機関は 海上保安庁で、プレジャーボート海難防止のため 様々な活動を推進している。ライフジャケットの常 時着用、携帯電話等の連絡手段の確保、海洋緊急通 報用電話番号 118 番の認識を基本とする自己救命策 確保キャンペーンを実施する啓発活動、ライブで海 の安全に関する情報を提供する沿岸域情報提供シス テム (MICS) 運用、機関故障海難を防止するための出 港前点検の周知活動を継続的に実施している。

それらに加えて海上保安庁では、安全で秩序ある 海洋レジャーの発展を図るためには民間主体の安全 活動の展開が不可欠であるとして、各種民間団体と 緊密な協力関係を構築している(12)。

プレジャーボートの運航者のための海上安全講 習や安全パトロール活動を行う小型船安全協会の 海難防止活動を支援し、特に沿岸域で発生する海難 への円滑な救助活動のために、(社) 日本水難救済会 や会員制救助サービス (BAN) を運用している (一財) 日本海洋レジャー安全・振興協会等の民間救助組織 との関係の構築、発展に力を入れている（表 2、表 3、 表 4、表 5 参照)。

\section{2 英国の政策}

海洋国家と呼ばれる英国では、多数の国民がボー 卜活動に参加している。英国海洋連合 (British Marine Federation)、英国王立ヨット協会 (Royal Yachting Association; 以下、RYA という)等の海洋 団体が実施した 2014 年の調查結果では、英国でボー 卜活動に参加している活動者は全成人人口の $7.1 \%$ である約 3, 459, 000 人、保有隻数は 1,214, 154 隻、 世帯当 1.4 隻であった ${ }^{(13)}$ 。

英国でプレジャーボートの安全管理を担当する 政府組織は海事沿岸警備庁 (Maritime and Coastguard Agency; 以下、MCA という)である。 MCA は各種民間団体と協力体制を構築し、民間団
体の活動を支援するシステムでプレジャーボートの 安全を管理している(14)。

プレジャーボートの登録は義務ではなく、自主的 登録を進めている。船舶の検査は、大きさ、使用目 的、航行水域によって船級や民間団体で実施してい る。

英国ではプレジャーボートを操縦するための資 格の取得を強制しないが、操縦能力の認定のために は、RYA が 14 種類の資格試験を実施、資格証を発給 している。しかし、講習等の水上レジャーサービス を提供する事業者は Adventure Activities Licensing Authority の安全管理システムの調査 を受け、資格証を取得する必要がある ${ }^{(15)}$ 。

英国ではプレジャーボートの活動や事業に関す る規制は存在しない。法的規制より教育活動を重視 し、子供を対象とした安全教育、各種イベントを活 用した親子教育などの実施で、長期にわたる安全文 化を造成している。 RYA 等の民間団体はこのような 教育訓練プログラムの運用、レジャー活動に関する 情報の提供を主に行い、海洋安全活動を展開してい $ろ^{(16)}$ 。

英国のプレジャーボート海難に対する救助活動 は MCA も海洋救助調整センターを設置し行っている が、徹底して大部分を民間が主導している。特に王 立救命艇協会 (Royal National Lifeboat Institution; 以下、RNLI という)が主導的に活躍し ている。RNLI は政府の支援を受けず寄付金で運用さ れる純粋なボランティア集団で 3 万人以上が活躍し ている。MCA と緊密に協力しながら海岸に救助要員 の配置、救助艇を利用したパトロール活動等で全国 的救助活動を展開している ${ }^{(17)}$ （表 2、表 3、表 4、表 5 参照)。

\section{4. 韓国海洋レジャー発達のための提案 4. 1 レジャ一活動区域制限の廃止}

韓国の海事安全法は、海上交通の秩序を確保する 名目で港湾区域や漁港区域にレジャー活動許可区域 を設定している。海上交通の秩序は交通主体相互の 注意が要求されることであり、どちらか一方の排除 のみで確保されることではない。海域は全ての利用 者に公平に利用する権利があるにも係らず、現在の 海事安全法は漁ろうや物の輸送という既存の海域の 利用形態を優先していると考えられる。

また、許可区域での活動には事前に書面による許 可が必要であるため、活動希望者の時間的利便性も、 
場所的利便性も阻害されている。この時間的、場所 的利便性が確保できないと、海洋レジャー施設に如 何に莫大な予算を投入しても、政策的に活性化努力 が継続されても、活動者は増え難く、その発達は遠 のくであろう。海洋レジャーの活性化と海洋文化振 興のためには海への距離を縮める必要がある。海へ の時間的、場所的距離を遠くする海洋レジャー活動 許可区域は廃止する必要があるものと考える。

しかし、海洋レジャー活動許可区域の設定で、プ レジャーボートを海上交通の頻繁な区域から遮断し てきたことで、衝突など大規模なプレジャーボート 事故は予防されてきたことは否定できない。船舶通 行量の多い沿岸で行われる小型で速度の速い水上才 一トバイ等のプレジャーボート活動の増加は、海難 やトラブルの可能性も高くする。日本の場合、プレ ジャーボートの活動範囲を制限せず、自由な活動を 保障してきたが、水上オートバイの不注意な運航や 悪質なマナーから発生する海難や被害の防止策とし て、地方条例を設定する自治体が増加している(北海 道プレジャーボート等事故防止等に関寸る条例、宮 崎県遊泳者及びプレジャーボートの事故防止に関す る条例等)。

従って海洋レジャー活動許可区域の廃止を推進 する為には、対象海域の現状を詳細に把握した上で、 海難の防止方策も講じながら段階的に緩和を推進す ることが望まれる。海洋レジャー許可区域の廃止で 予想される海難の防止には、海上交通量の多い海域 の管制を徹底することや、警備艇のパトロール活動 を増加させる等の監視システムの強化が必要である。 また、プレジャーボートの活動に合わせた推薦航路 や活動海域の情報を提供することで、危険海域への 船舶の密集を防止することも可能である。このよう な政策的努力と活動者教育で安全意識を強化するこ とは、海上交通の安全につながると考える。

\section{2 利用者教育の強化}

現在のプレジャーボート教育は免許取得教育と 7 年毎の更新講習に限られている。教育の内容は海事 法規、プレジャーボートの管理、人命救助等の水上 レジャー安全法上決められた内容で、一律に 180 分 間行われている。義務的参加ではあるもののこの講 習を効果的な教育にするためにはコンテンツの工夫 が必要で、法に規定されている内容を含める受講団 体、時期、海域別特性を考慮した分かりや寸いコン テンツの補強が必要である。
免許の更新講習以外に、海洋活動に必要な安全意 識を育てるための教育機会を拡大していくことも 大事である。海洋レジャ一活動に関心を持つ一般の 人が簡単な検索で見られるように動画等の教育資料 を製作し関連機関のウェブサイト上に公開すること なども、必要者には利便性が高く教育の効果が期待 できる。また、幼稚園、小学校の子供対象の水上安 全教室を開催し、小さい時から安全を大事にする文 化を作っていくことも長期的に効果があると考える。

しかし、韓国の海洋レジャー文化はまだ大衆化し ていない分、教育を担当する専門家の数も多くない。 操縦免許の更新講習を代行している団体もまだ零細 であることから、教育コンテンツの開発に多く投資 することも容易ではない。従って、プレジャーボー 卜活動者に対する質のいい教育が行われるためには、 海洋レジャー分野の専門家養成のための努力と同時 に政府主導の教育コンテンツの開発と普及が必要で ある。海洋レジャーの現場で活躍する専門家が増え ることで、民間レベルの良質の教育活動が可能にな っていくことが予想される。

\section{3 海洋警備安全本部の変化と新たな沿岸救 助システムの構築}

プレジャーボートの安全を確保するため活動者 の安全意識を高めることは何より重要なことではあ るが、それは短期に達成できることではない。活動 者の教育を進めながら、海難防止を目的にする積極 的安全活動も必要である。現在、海洋警備安全本部 の活動は、海難の防止よりは事故発生後の対応に、 一般海域よりは事業場の対応に集中している。この プレジャーボートに対する安全活動を、事前予防を 中心に、また一般海域活動者を対象にする活動へと 方向を転換しなければならない。持続的パトロール で得られた海域情報をライブで活動者に提供するサ ービスで安全な活動を図り、プレジャーボートや海 洋レジャ一装備の発達に合わせた救助装備を拡充し 救助スキル向上のための訓練も強化しなければなら ない。上記のような努力で全国の沿岸で十分な効果 を得るためには、海洋警備安全本部に十分な人材の 増員と装備予算の投入が要求される。

しかし、政府の人材と予算の問題は複雑な調整が 必要なため、プレジャーボート活動者の増加に合わ せてすぐに救助勢力を増やすことは難しい。また、 如何に救助勢力を確保したとしても、現在、1件の 事故において曳航まで全てを負担するシステムでは、 
低速で長時間を要する曳航の特性から、複数の海難 発生時など、効果的な対応は困難である。

従って日本の (社) 日本水難救済会や英国の RNLI のような民間勢力を活用した、新たな沿岸救助体制 の構築が必要である。海洋警備安全本部と民間のコ ミュニケーションを緊密にし、沿岸の近い場所での 単純漂流、機関故障などの軽微な事故発生時の曳航 は救助能力のある民間の勢力が対応し、海洋警備安 全本部は遠距離や緊急を要する海難の救助に集中す るシステムの構築で効率のいい海難対応が可能にな ると考える。

\section{4 民間の安全活動支援}

民間の勢力を活用した沿岸救助システムの構築 のためには、民間団体の活動を活性化する方策から 考えなければならない。現在、(社) 水上レジャー安 全協会、韓国マリーナ協会、韓国海洋レジャーネッ トワーク等のプレジャーボート活動者の団体が設立 され活動しているが、その活動は政府にからの操縦 免許実技試験の委託や海洋レジャー体験等の活動を 中心にしている。親睦や情報交換を目的とした団体 活動に、教育や救助活動を加えることによって公益 活動としての側面を持たせることが団体の構成と維 持に効果的であると考える。マリーナ等の組織化の 促進が同好の志の仲間による相互扶助としての海難 救助に役立つことが指摘されており ${ }^{(18)}$ 、義務として 強制されない同好団体での教育や安全活動は、海難 救助に大いに貢献するものと考えられる。このよう な民間の団体の組織化を図ることは海洋レジャーの 安全確保に寄与寸るものである。

レジャー活動者の量的成長と共に活動者の安全

表 6 韓国の海洋レジャー発達のための改善策

\begin{tabular}{|c|c|}
\hline 主体 & 改善内容 \\
\hline $\begin{array}{l}\text { 政府 } \\
\text { (自治体) }\end{array}$ & $\begin{array}{l}\text { ·海洋レジャー許可区域制度の段階的緩和 } \\
\text {-海域管制や海上パトロールの強化、安全海域情報提供 } \\
\text { ·利用者教育の強化 } \\
\text {-教育コンテンツの補強、教育資料の製作と一般提供 } \\
\text {-子供対象水上安全教室開催 } \\
\text {-海洋レジャー分野の専門家育成 } \\
\text { ·沿岸救助システムの改善 } \\
\text {-救助人カ増員や装備の拡充、救助スキルの向上訓練の強化 } \\
\text { ·民間の安全活動支援 } \\
\text {-安全教育の資料提供、救助方法の指導 } \\
\text {-安全活動の実費支援 } \\
\text {-民間団体間䈍談会開催等 }\end{array}$ \\
\hline 民間団体 & $\begin{array}{l}\text { ·自主的安全活動の展開 } \\
\text {-救助活動や教育活動の推進 }\end{array}$ \\
\hline 個人 & $\begin{array}{l}\text { ·航海知識や操縦スキルの訓練 } \\
\text { ·安全意識の向上 }\end{array}$ \\
\hline
\end{tabular}

意識の質的成長を促すためには、民間の自律的安全 活動をサポートする必要がある。安全教育に必要な 資料の提供、各活動の特性に合わせた救助方法の指 導、法規改正などの情報提供などは安全で楽しい海 洋レジャー環境作りに貢献するものと思われる。ま た、救助活動を実践する団体にガソリン代など安全 活動の実費支援、海洋警備安全本部の公務員採用時 ボランティア活動者にインセンティブ付与、団体間 情報交流のための懇談会の開催など、政府の積極的 支援が必要であり、その支援の下、自治体及び民間 団体、個人による活動が不可欠である ${ }^{(19)}$ (表 6 参照)。

\section{5. 終わりに}

韓国、日本、英国はプレジャーボートの安全を確 保するために様々な努力を続けているが、国別に異 なる形をしている。英国は法律や制度的規制は無く、 活動者教育から救助活動までの安全活動のほぼ全て が民間団体の自主的努力で行われている。政府はそ の活動を尊重し、積極的にサポートしている。日本 は最小限の安全を確保するため、法律や制度を設け 政府の管理システムを運用しながら、活動者の自主 的安全活動をサポートしている。韓国は政府が主導 し、法律や制度で、事業者や活動者の活動を規制す ることで安全を確保している。プレジャーボートの 活動を大衆化していくためには、英国と日本のよう に活動者の自主的活動を活性化する方向に向かうべ きだと考える。

今後、韓国において安全で楽しい海洋レジャー文 化が根付くためには政府の規制の力ではなく、個人 の自主的努力で安全意識を高めなければならない。 海上活動中発生するトラブルへの対応を政府の活動 に依存することは、救助費用等の負担がないことか ら短期的には活動者に歓迎されるかも知れないが、 自主的努力が欠けることで長期的に安全な海洋レジ ヤー文化を造成するには望ましいことではない。安 全な海洋文化を創るには次のような個人と民間団体 と政府の努力を重ねなければならない。

まず、個人のスキルアップのための努力である。 知識やスキルの不足は事故の原因となるため、常に 搭載装備の取り扱い方の習得や、海域情報等を収集 しなければならない。知識の習得と同時に重要なこ とが安全意識を高めることである。安全の確認には 適当な妥協を排除し、抱いた疑問には責任を持って 対応寸る習慣を身に付ける努力が必要である。

次に必要なことは民間団体の自律的安全活動展 
開のための努力である。海上のボートを対象にする 安全活動はその環境や装備の特性から、個人レベル では限界があるので、団体レベルの体系的活動が効 果的である。民間団体は救助活動等の共益活動を推 進することで、活動の意味をより梁くし、会員間の 結束を強化し、安全意識を高める効果も期待できる。 そのため、各団体はその規模と会員の力量を考慮し た安全活動を進めていくことが望ましい。

最後は、個人と民間団体の努力を積極的にサポー ト寸るための政府の努力である。韓国政府は海洋レ ジャーの普及のための施設投資と共に、活動の障害 になっている規制等の政策を検討していかなければ ならない。現在、海洋レジャー安全管理活動を政府 が担当しているが、民間レベルの自主的安全活動の 可能な施設的、制度的環境を創ることも政府の役割 である。

このように個人、民間団体、政府の努力が調和を 続けることで、韓国の海洋レジャー活動は少数の独 特な趣味活動のレベルを超え、新しい文化として発 展することができると考える。

\section{参考文献}

(1) Chan-Ryong Kim·Jae-Hyung Lee :

A Course Development of the Marine Leisure Sport Policy,

Journul of Navigation and Port Research, vol. 32, No. 5, pp. 418-420, 2008.

(2) 국토해양부 (国土海洋部):

제 2 차해양수산발전계획 (第 2 次海洋水産発 展基本計画), pp. 137-138, 2010.

(3) 해양경 찰청(海洋警察庁) :

2013 해양경찰백서(2013 海洋警察白書), pp. 124-149, 2013.

(4) 국민안전처(国民安全処) : 2015 국민안전처통계연보(2015 国民安全処 統計年報), pp. 322-323, 2015.

(5) Korea Maritime Institute :

Policy Direction for Promotion of Marine Leisure Sports, pp. 19, 29, 2013.

（6）上園政裕：海洋性レクリエーションの現状と展 望, 船とレジャー, pp. 2-4, 関西造船協会, 1990.

（7）（財)ブルーシー・アンド・グリーンランド財団： 海洋性レクリエーションの現状と展望, pp. 11-14, 2001.
（8）수상레저안전법(水上レジャー安全法): 국가법령정보센터 (国家法令情報センター) http://www. law. go. kr/1sInfoP. do?1siSeq=17 0984\&efYd=20151119, 2016. 6. 30.

（9）수상레저종합정보(水上レジャー総合情報) http://wrms.kcg.go.kr/wlh/jsp/wli/wli_prohi bition.jsp, 2016. 6. 30.

(10）日本小型船舶検查機構 : 年度別統計データ http://www. jci.go. jp/jci/pdf/toukei/year_ zaiseki_h27.pdf, 2016. 6. 30.

(11) 日本海洋レジャー安全·振興協会 : 免許の取得, https://www. jmra. or. jp/license, 2016. 6. 30.

(12) 海上保安庁 : 海上保安レポート 2014

(13) Watersports Participation Survey 2014 http://www. rya. org. uk/SiteCollectionDocum ents/sportsdevelopment/Watersports_Survey _2014_Executive_Summary.pdf, 2016. 6. 20.

（14）山地哲也：自己責任がベース 英国のプレジャ ーボートの安全対策，海と安全，No. 515, pp. 14-16, 2002.

(15) 해양경찰청 (海洋警察庁) : 수상레저활성화를 위한 중장기 발전방안 연구(水上レジャー 活性化のための中長期発展方案研究), pp. 37-42, 2012.

(16) Royal Yachting Association: Pleasure Craft Regulations, http://www. rya. org. uk/knowledge-advice/re gulations/pleasure-craft/Pages/hub. aspx, 2016. 9. 15.

(17) Woo-Jeong Cho $\cdot$ Bo-Young Jang : Analyses of the Advanced Countries' Related Regulations and Perceptions to Improvement Directions for Water Leisure Activation, Journul of Navigation and Port Research, vol. 37, No. 4, pp. 420-421, 2013.

(18) 藤岡賢治 : 海難政策論 (改訂版), pp. 157-158, 成山堂書店, 1994.

(19) 藤岡賢治 : 海難における救助責任とその費用負 担, 海上保安と海難, pp. 9-10, 中央法規出版株式会社, 1996. 